\title{
First record of stubby-root nematode (Paratrichodorus porosus) associated with barley in Australia
}

\author{
J. G. Sheedy ${ }^{\mathrm{A}, \mathrm{C}}$, T. G. Clewett ${ }^{\mathrm{A}}$, M. Hodda ${ }^{\mathrm{B}}$ and J. P. Thompson ${ }^{\mathrm{A}}$ \\ A Leslie Research Centre, Agri-Science Queensland, Department of Employment, Economic Development \\ and Innovation, PO Box 2282, Toowoomba, Qld 4350, Australia. \\ ${ }^{\mathrm{B}}$ CSIRO Entomology, GPO Box 1700, Canberra, ACT 2601, Australia. \\ ${ }^{\mathrm{C} C}$ Corresponding author. Email: jason.sheedy@deedi.qld.gov.au
}

\begin{abstract}
High populations (5000 to $20000 / \mathrm{kg}$ soil) of the stubby-root nematode Paratrichodorus porosus were identified morphologically from soil samples taken under patches of poorly growing barley in a field between Yuleba and Surat in western Queensland, Australia. Lower populations $(<4000 / \mathrm{kg}$ soil) were recovered from soil samples taken from asymptomatic barley. This is the first record of this nematode species on barley in Australia.
\end{abstract}

In 2008, a 130-ha irrigated crop of barley (Hordeum vulgare cv. Dictator) being grown for hay on a brown Kandosol (Isbell 2002) (pH 6.0; 88\% sand; 5\% silt; 7\% clay) between Yuleba and Surat, Queensland $\left(26.98547^{\circ} \mathrm{S} 149.27344^{\circ} \mathrm{E}, 244 \mathrm{~m}\right.$ elevation) had large patches of poor growth over a 20 -ha portion of the field. The crop had been planted on June 14 with $40 \mathrm{~kg} / \mathrm{ha}$ monoammonium phosphate (MAP: $10 \% \mathrm{~N}, 22 \% \mathrm{P}, 1.5 \% \mathrm{~S}$ ) and fertilised with $200 \mathrm{~kg} /$ ha urea $(46 \% \mathrm{~N})$ on July 15 and then irrigated. At the beginning of anthesis, asymptomatic plants had normal growth, biomass and a height over $1 \mathrm{~m}$, whereas symptomatic plants were visibly stunted $(<30 \mathrm{~cm}$ high) with severely reduced biomass. Three samples each of symptomatic and asymptomatic groups of whole plants from $20 \mathrm{~cm}$ of row and soil to $15-\mathrm{cm}$ depth were collected from different areas within the 20-ha portion.

Each soil and root sample was thoroughly mixed with roots cut into $\sim 1$-cm lengths. Gravimetric moisture content was determined by drying a 100 -g subsample at $105^{\circ} \mathrm{C}$ for $48 \mathrm{~h}$. Nematodes were extracted from a 200-g subsample from each soil sample using the Whitehead tray method (Whitehead and Hemming 1965) for $48 \mathrm{~h}$ at $22^{\circ} \mathrm{C}$ and collected on a $20-\mu \mathrm{m}$-aperture sieve. Samples were stored in $\sim 15 \mathrm{~mL}$ of water at $3^{\circ} \mathrm{C}$. Nematode populations were counted under a compound microscope $(100 \times)$ using a Hawksley slide counting chamber of $1-\mathrm{mL}$ capacity. After assessment, nematodes were submitted to the Australian National Insect Collection (Canberra, Australia) for species identification.

Morphological identifications were conducted initially on immobilised specimens in water. Identifications were confirmed on specimens fixed in formaldehyde for 2 weeks, then processed to glycerol by the slow method and mounted on permanent slides (Hooper 1986).

The nematodes were on average $353 \mu \mathrm{m}$ long $(307-378 \mu \mathrm{m})$, average vulval position of $54 \%(52-56 \%)$, had onchiostyles between 42 and $50 \mu \mathrm{m}$ long, excretory pore anterior to pharynx base, medioventral body pores, anterodorsal overlap of intestine, oesophageal bulb, no males, pore-shaped vulva in ventral view, oval, oblique and separated vaginal cuticular pieces and a convex-conoid tail. The most distinctive diagnostic characters were the excretory pore much anterior to the oesophago-intestinal junction, the anterodorsal overlap of the oesophagus of the intestine and the absence of males. Female body length was shorter than, but vulval position was consistent with published ranges; however, neither trait is generally considered diagnostic (Decraemer 1995). Of the seven species of Paratrichodorus identified in Australia (P. minor, P. lobatus, $P$. porosus, $P$. renifer, $P$. queenslandensis, $P$. orrae and $P$. mirzai) (Decraemer and Reay 1991; McLeod et al. 1994), this combination of characters is present in $P$. porosus only (Table 1).

$P$. porosus populations were 5053, 10139 and $20216 / \mathrm{kg}$ soil (oven-dry equivalent) in samples from areas with symptomatic plants and 320, 507 and 4101/kg soil in samples from areas with asymptomatic plants. Examination of the root systems showed that asymptomatic plants had normal root development while symptomatic plants had severe root damage including black lesions, stunting of lateral roots and absence of root-hairs.

Further investigation was done in a glasshouse pot study using pregerminated barley cv. NRB04182 plants in 7-cm-square by 15 -cm-high plastic pots containing $330 \mathrm{~g}$ of remnant soil from the poor growth area with a $P$. porosus concentration of $5053 / \mathrm{kg}$. Each pot was fertilised with $1 \mathrm{~g}$ of Osmocote ${ }^{\circledR}$ Native Gardens plus micronutrients (17-1.6-8.7 NPK) slow-release fertiliser mixed through the soil and grown on glasshouse benches fitted with a bottom watering system regulated by a float valve set to a water tension of $2 \mathrm{~cm}$. After 10 weeks growth, root systems were visually examined and a 1-g subsample stained for root-infecting fungi (Phillips and Hayman 1970). No evidence of phytoparasitic fungi was observed on the root systems of the glasshouse-grown 


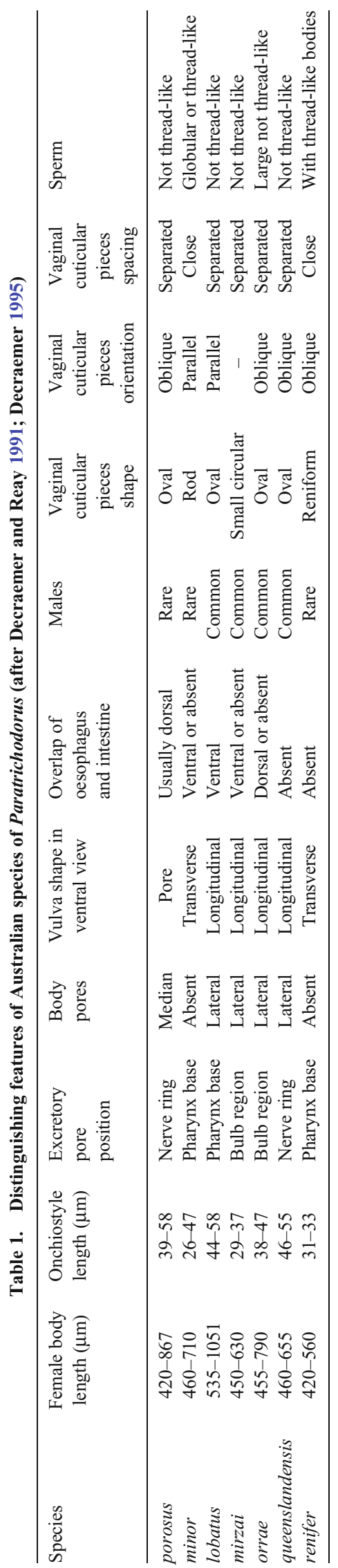




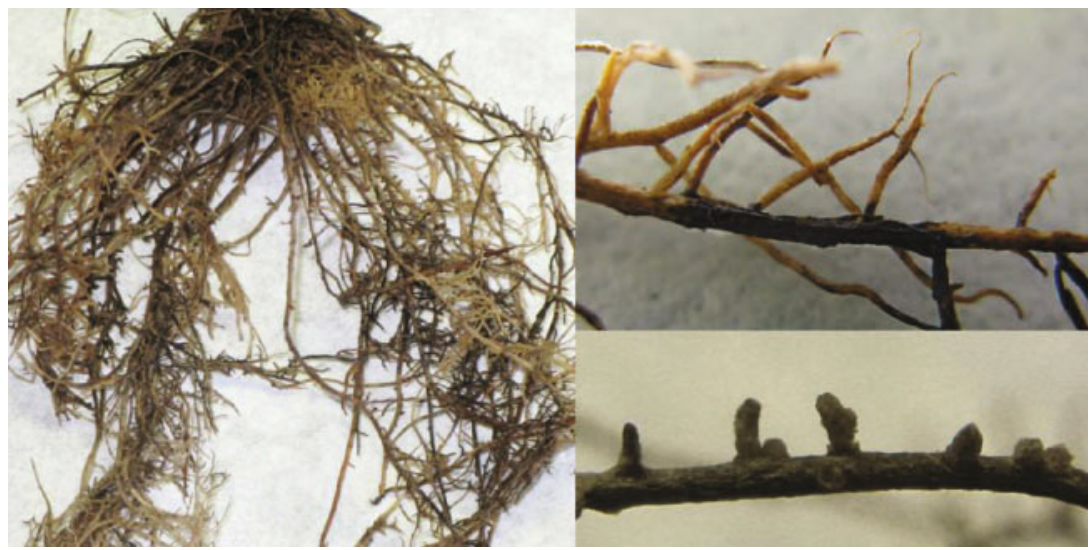

Fig. 1. Root system of barley cv. NRB04182 showing blackening, stunting of lateral roots and no root-hair production after 10 weeks glasshouse growth in field soil infested with 5053 Paratrichodorus porosus $/ \mathrm{kg}$.

barley cv. NRB04182, which displayed similar symptoms to the barley cv. Dictator root systems observed from symptomatic field plants (Fig. 1).

$P$. porosus has previously been recorded in Queensland, New South Wales and Western Australia (McLeod et al. 1994) with the most recent report specifically indentifying $P$. porosus in a survey of Queensland sugarcane fields where it occurred in $<1 \%$ of samples (Blair et al. 1999). However, Paratrichodorus spp. have previously been associated with sugarcane (Saccharum sp.) (Blair et al. 1999; Blair and Stirling 2007), citrus (Citrus spp.) (Brown 1978; Walker and Morey 1999) and other fruit trees (Sauer 1981), leeks (Allium ampeloparsum) (Hall et al. 2007), grapes (Vitis sp.) (Stirling 1976; Harris 1983), carrot (Daucus carota) (Walker 2004) and wheat (Triticum aestivum) (Suatmadji 1984). These reports have identified Paratrichodorus spp. in a range of soil types; however, high sand-content soils were most common with Blair et al. (1999) finding that the mean densities of Paratrichodorus spp. were significantly higher in sandy loams with greater than $75 \%$ sand (coarse and fine) than all other soil types. A recent review by Hodda and Nobbs (2008) found that of the seven species of Paratrichodorus present in Australia, only $P$. minor and $P$. porosus have been associated with damage of major agricultural species outside the Australasian region.

This is the first report of $P$. porosus associated with poor growth of barley in Australia. Observations by the property owners suggested that barley cv. Fitzroy and a mixed planting of barley cvv. Mackay and Grout also suffered from patchy poor growth during 2007 and 2009, respectively. Little is known of the distribution of $P$. porosus in broadacre cropping systems or the host status of many of the economically important crops in Queensland. Initially, glasshouse studies would be valuable to assess the host status of economically important crop species and cultivars. Additionally, targeted sampling of lighter-textured soils would be useful to ascertain the extent of $P$. porosus distribution.

\section{Acknowledgements}

The authors thank Lindsay Ward (Ward Agriculture) and Greg Platz (Agri-Science Queensland) for initial collection of soil and plant samples and David and Matthew McInnerney for allowing sampling to be done on their property.

\section{References}

Blair BL, Stirling GR (2007) The role of plant-parasitic nematodes in reducing yield of sugarcane in fine-textured soils in Queensland, Australia. Australian Journal of Experimental Agriculture 47, 620-634. doi:10.1071/EA05287

Blair BL, Stirling GR, Whittle PJL (1999) Distribution of pest nematodes on sugarcane in south Queensland and relationship to soil texture, cultivar, crop age and region. Australian Journal of Experimental Agriculture 39, 43-49. doi:10.1071/ea98085

Brown RH (1978) The distribution of Tylenchus semipenetrans and other parasitic nematodes associated with citrus in northern Victoria. Australian Journal of Experimental Agriculture and Animal Husbandry 18, 148-151. doi:10.1071/EA9780148

Decraemer W (1995) 'The family Trichodoridae: stubby root and virus vector nematodes.' (Kluwer Academic: Dordrecht)

Decraemer W, Reay F (1991) Trichodorid nematodes from Australia with description of two new species from native vegetation. Australasian Plant Pathology 20, 52-66. doi:10.1071/APP9910052

Hall BH, Hitch CJ, Oxspring EA, Wicks TJ (2007) Leek diseases in Australia. Australasian Plant Pathology 36, 383-388. doi:10.1071/ AP07038

Harris AR (1983) Distribution of parasitic nematodes in vineyards in central and north-eastern Victoria. Australian Journal of Experimental Agriculture and Animal Husbandry 23, 221-224. doi:10.1071/ EA9830221

Hodda M, Nobbs J (2008) A review of current knowledge on particular taxonomic features of the Australasian nematode fauna, with special emphasis on plant feeders. Australasian Plant Pathology 37, 308-317. doi:10.1071/AP08024

Hooper DJ (1986) Handling, fixing, staining and mounting nematodes. In 'Laboratory Methods for Work with Plant and Soil Nematodes'. (Ed. JF Southey) pp. 59-80. (Her Majesty's Stationery Office: London) Isbell RF (2002) 'The Australian Soil Classification (Revised Edition).' (CSIRO Publishing: Collingwood, Vic.)

McLeod R, Reay F, Smyth J (1994) 'Plant nematodes of Australia listed by plant and by genus.' (NSW Agriculture: Orange) 201 pp.

Phillips JM, Hayman DS (1970) Improved procedure of clearing roots and staining parasitic and VAM fungi for rapid assessment of infection. Transactions of the British Mycological Society 55, 158-161. doi:10.1016/S0007-1536(70)80110-3 
Sauer MR (1981) Plant nematodes associated with fruit trees in northern Australia. Australian Journal of Experimental Agriculture and Animal Husbandry 21, 129-131. doi:10.1071/EA9810129

Stirling GR (1976) Distribution of parasitic nematodes in South Australian vineyards. Australian Journal of Experimental Agriculture and Animal Husbandry 16, 588-591. doi:10.1071/EA9760588

Suatmadji RW (1984) A technique for subtracting nematodes from soil by mechanical destruction, with special reference to studies on the relation between Paratrichodorus sp. and wheat. Australasian Plant Pathology 13, 17-18. doi:10.1071/APP9840017

Walker GE (2004) Associations between carrot defects and nematodes in South Australia. Australasian Plant Pathology 33, 579-584. doi:10.1071/ AP04059
Walker GE, Morey BG (1999) Effect of brassica and weed manures on abundance of Tylenchus semipenetrans and fungi in citrus orchard soil. Australian Journal of Experimental Agriculture 39, 65-72. doi:10.1071/ EA97116

Whitehead AG, Hemming JR (1965) A comparison of some quantitative methods of extracting small vermiform nematodes from soil. The Annals of Applied Biology 55, 25-38. doi:10.1111/j.1744-7348.1965. tb07864.x

Manuscript received 26 November 2009, accepted 3 June 2010 